\title{
Biblical Translations and Literalness in Early Modern Spain ${ }^{1}$
}

\author{
Fernando Rodríguez Mediano
}

In his edition of the Inquisition's trial of Fray Luis de León (around the 1570s), Ángel Alcalá provides a summary of the accusations made against the professor of Theology and Sacred Scripture from Salamanca and his colleagues. Among them, we find the following:

The Song of Songs is a love poem written by Solomon to the Pharaoh's daughter, and to teach anything else is absurd; the Song can be read and explained in the vernacular tongue; when citing explanations by the Saints that run counter to their own, they wave them aside and dismiss them as allegories. One of these authors has the habit of saying, 'Here comes el sabio Alegorín (Alegorín the Wise)' if he is cited; there is no allegorical meaning in the Scriptures. ${ }^{2}$

As has been pointed out by Ángel Alcalá himself along with other historians, the trial of Fray Luis did not revolve so much around the fact of having translated a biblical text into the vernacular (though this was also part of the accusation), but rather around his criticism of the Vulgate and defense of a literal rather than an allegorical interpretation. ${ }^{3}$

1 The research leading to these results has received funding from the European Research Council under the European Union's Seventh Framework Programme (FP7/2007-2013) ERC Grant Agreement number 323316, CORPI project 'Conversion, Overlapping Religiosities, Polemics, Interaction. Early Modern Iberia and Beyond'. This contribution was translated into English by Nicholas Callaway.

2 'El Cantar de los cantares es un poema amoroso de Salomón a la hija del Faraón, y enseñar lo contario es fútil; el Cantar se puede leer y explicar en lengua vernacular; cuando se aducen explicaciones de los Santos contrarios a las suyas las tienen en nada y las tachan de alegorías. Uno de esos autores acostumbra a decir "Ya está el sabio Alegorín" si le aducen; en las Escrituras no hay sentido alegórico'; Ángel Alcalá, El proceso inquisitorial de Fray Luis de León, and ed. (Valladolid: Junta de Castilla y León, 2009), pp. xxxii-xxxiii.

3 Colin P. Thompson, The Strife of Tongues: Fray Luis de León and the Golden Age of Spain (Cambridge: Cambridge University Press, 1988), p. 60.

(C) FERNANDO RODRÍGUEZ MEDIANO, 2016 | DOI 10.1163/9789004324329_004

This is an open access chapter distributed under the terms of the CC-BY-NC-ND License. 
This essay will address the problem of literalness, starting with the relationship between the interpretation and the translation of the Bible (insofar as literalness is the first interpretive question that the translator is faced with). It is important to bear in mind the uniqueness of a certain medieval Spanish biblical tradition, which in simplified terms could be described as: more respectful of the differences between manuscripts, closer to the Hebrew tradition than to the Vulgate, closer to the text of the Bible than to the Church Fathers. Moreover, this was a local tradition that ran in parallel to Hispanic Judaism, which was more closely attached to philological and grammatical analysis of Scripture. ${ }^{4}$

This medieval Hispanic tradition resulted in a sizable output of Bibles in Hebrew, ${ }^{5}$ but also of translations into the vernacular Romance languages, which were carried out by Jews. Some of these Romance translations were made for the Jewish communities' internal use, but the majority of those that have survived appear to have been made for Christian patrons. The most famous example is without a doubt the so-called Alba Bible, an extraordinary manuscript completed in 1430, which contains a translation made by Rabbi Moses Arragel of Guadalajara for the Grand Master of the Order of Calatrava. More influential still was the translation made by Yom Țov Atias and Abraham Usque, 'word for word and from the true Hebrew', printed in Ferrara in 1553. The Ferrara Bible and its literal translation were mainly aimed at the Sephardic Jewish readership, but its influence was to extend much further, as we shall see is some of the examples to come. ${ }^{6}$

In parallel to the production of translations into Spanish, there was also a growing movement to repress them. ${ }^{7}$ Apart from a handful of cases during the medieval period, we may cite the (unsubstantiated) prohibition by the Catholic Monarchs; the (equally debated) prohibition by Carlos V, coinciding with the Reform crisis; and, lastly, the inclusion of translations of the Bible in the Index of Forbidden Books starting in the 1550s. Although this prohibition must be heavily qualified (the prohibition sometimes referred to the Bible as a whole but not to its parts), it is clear that the repression grew steadily

4 David Coles, 'Humanism and the Bible in Renaissance Spain and Italy: Antonio de Nebrija (1441-1522)', (PhD Diss., Yale University and Umi Ann Arbor, 1983), vol. 1, p. 9.

5 Francisco Javier del Barco (cur.) Biblias de Sefarad / Bibles of Sefarad (Madrid: BNE, 2012).

6 For a general overview, see Iacob M. Hassán (ed.), Introducción a la Biblia de Ferrara. Actas del Simposio Internacional, Sevilla, noviembre de 1991 (Madrid: Sociedad Estatal Quinto Centenario, 1994); and more specifically, along the lines of this article, see esp. Natalio Fernández Marcos, 'La Biblia de Ferrara y sus efectos en las traducciones bíblicas al español', pp. 445-71.

7 For a general overview of this subject, see Sergio Fernández López, Lectura y prohibición de la Biblia en lengua vulgar. Defensores y detractores (León: Universidad de León, 2003), esp. pp. 89-150. 
throughout the second half of the sixteenth century, alongside the persecution of other religious books, like Muslim or Jewish books. Of course, this persecution can be linked to the Tridentine decrees, which defended the authority of the Vulgate, marking a critical break with the reformed world. The persecution of biblical translation had a number of consequences. In general, the great translations of the Bible into Spanish (the Biblia del Oso by Casiodoro de Reina, the translation of the Gospels by Francisco de Enzinas, and others) are related to the Protestant world. In Spain many vernacular translations of the Bible were destroyed. And yet, as we shall see, this persecution of the Bible in Romance vernacular was challenged, debated and, ultimately, did not keep the text of the Bible from being disseminated in a variety of ways. This situation poses the problem of the unique relationship between the Spanish language and the linguistic model of the Bible.

Over the following pages I have gathered together diverse material on the history of the interpretation, translation and uses of the Bible in early modern Spain, organizing them into three different sections. In the first, starting with the problem of translation, and of equating translation with interpretation, I pose the question of how people conceived of the relationship between Spanish and Hebrew, and how and to what extent this was considered a linguistic, rhetorical and literary model. In the second part, I attempt to illustrate the tension between literalness and allegory as one of the central elements in the construction of the problem of representation, which is of critical importance in the development of logic and of speculative grammar. As seen in the example of Juan Caramuel, this tension attains its fullest expression in the semiotic dimension of the Eucharist. Lastly, in the third section, I give an account of various controversies arising from the translation and literal interpretation of the Bible. The cases of Valdés and of Arias Montano are very important examples of the construction of forms of spirituality tied to Biblical interpretation. On the other hand, that of Furió Ceriol poses the fundamental problem of translating the Bible into Romance, a controversy that not only marked the frontier between Reformation and Counter-Reformation, but also shaped more subtle differences connected to complex and selective forms of disseminating the Bible and its translations. Based on these examples, and on the related problems that they raise, I propose several lines of research that I find to be indispensable when addressing the problem of the translation, interpretation and spread of the Bible in early modern Spain, which remains relatively unexplored. 


\section{A Model of Translation, a Literary Model}

In 1778, Juan Antonio Pellicer y Saforcada published an Ensayo de una Bibliotheca de traductores españoles (Attempt at a Library of Spanish Translators). ${ }^{8}$ It was an incomplete work, as the author himself admitted, and had one problem: when listing all of the Spanish translators of the Scriptures, 'I found myself obligated to cite some heterodox authors, whose work has preserved references to these translators; since those of our nation generally endeavor to silence them. ${ }^{9}$ Old Hebrew, Latin or Spanish translations were not only of benefit to the nation, but also served to enrich the language. The relationship between different translations, and the construction of an expressive and literary model of Spanish, posed a recurring problem in rhetorical and grammatical terms. At nearly the same time as Pellicer y Saforcada, the Count of Campomanes complained of the lack of a fixed style for Spanish, and of the neglect of Spanish rhetoric. Concerning translation, Campomanes regretted the fact of 'not having proper translations of the textual works of ancient and modern Philosophy, Medicine, the Holy Fathers, and other areas of History and Mathematics'. This was the reason why each individual professor translated the concepts of the various sciences into Spanish as best he could, without conceptual precision, and leading to 'linguistic inconsistency'. In addition, the practice of translation also posed a serious methodological problem: literal, word-for-word translation ran the risk of disturbing the grammar of the Spanish, introducing all sorts of calques and corrupting the natural order of its syntax. Faced with the troubles of literal translation, it was the translator's task 'to translate the author's meaning; literally when the language allows it, and when it does not, to faithfully render the concept without respecting every word of the sentence.10

Juan Antonio Pellicer y Saforcada, Ensayo de una Bibliotheca de traductores españoles donde se da noticia de las traducciones que hay en castellano de la Sagrada Escritura, Santos Padres, filósofos, oradores, poetas, así griegos como latinos (Madrid: Antonio Sancha, 1778 ) [facsim ed., Cáceres: Universidad de Extremadura, 2002].

'Me he visto en la necesidad de citar algunos autores heterodoxos, en cuyas obras se conservan todavía noticias de aquellos traductores; pues los de nuestra nación hacen generalmente estudio de callarlas'; Pellicer, 'Prólogo', in Ensayo de una Bibliotheca.

'No aver traducción ajustada de las obras textuales de la Philosofía antigua y moderna, medicina, Santos Padres y demás partes de la historia y mathemáticas'; 'trasladar el sentido del autor, literalmente quando el idioma lo permite, y quando no poner el concepto fielmente sin atenerse a la letra en frase equivalente'. Fundación Universitaria Española [FUE], Count of Campomanes, Papeles, fols. 6o-20: 'Pensamiento del estado de la lengua y estilo español', paragraphs 20 and 21. Among the documents belonging to the Count of 
The principle of striking a balance between a literal translation and a translation of meaning, a balance capable of preserving the purity of the Spanish language, is a rather simplistic commonplace that one sees repeated over and over in the statements of intent of countless translators who seem to be constantly repeating this problematic experience of reproducing the meaning of the original text while respecting the expressivity of the target language. It is a problem that is echoed time and again, and was often resolved by relying on the authority of St Jerome and his experience as Bible translator, based on the actually rather vague formula of 'matching it literally wherever it suited the spirit of our language and, where it did not, abandoning it, matching the meaning alone.'11 However, beyond this commonplace, the practice of translation reflects a much more complex situation, where translators' choices adapt, in a variety of ways, not only to the problem of more or less appropriate means of transferring a meaning, but also to the problem of responding to different criteria of textual or religious authority. This issue is particularly complex when it comes to the Bible. There is, first of all, the dispute surrounding the translation of the sacred text into the vernacular, repeating the arguments about the latter's suitability for the word of God, or the possibility of betraying it. Here one can see, I think, the parallel between literal translation (in its most basic technical form, that is, word-for-word translation) and literal exegesis on the one hand, and between the translation of meaning and allegorical exegesis on the other. Based on this simple premise, I would like to explore how the translation of the Bible, and the use of Hebrew, influenced reflections on the use of Spanish, which is part of a broader question about the uses of the Bible and Eastern antiquity in early modern Spain.

Beginning with Pellicer y Saforcada's book itself, the first entry of the dictionary ${ }^{12}$ is about Fray Alberto de Aguayo's Spanish translation of Boethius' De consolatione philosophiae, first printed in Seville in 1518. Aguayo himself defended his translation as the best that had been made of the work of Boethius, because he 'had rendered [it] from Latin into Spanish, not word by word, but sentence by sentence; not discarding something of his and adding something of mine, for, when translating books, one must not use words as a measure, but must weigh them by their sentences'. He then added,

Campomanes there are also papers about Bible translation, including fragments of actual translations of the same.

'ajustarse a la letra, siempre que se conformaba a con el genio de nuestra lengua, y donde no, desampararla, ajustándose solo al sentido'; Pellicer, Ensayo de una Bibliotheca, p. 84, quoting Jerónimo Gómez de Huerta.

Pellicer, Ensayo de una Bibliotheca, pp. 3-7. 
And should anyone find it frivolous to write a thing in verse, as the things people know the least about are the ones that receive the most criticism, he should know that this was the manner of speaking and writing of Moses, David, Solomon, and many of the Prophets, and many Saints of the New Testament, and even the Lord of one and all of them did not abhor this way of speaking when He said: Heli, heli, lamma sabacthani!, and elsewhere: Non dico tibi septies, sed usque septuagies septies ['I tell you, not seven times, but seventy-seven times', Matthew 18:22]. And, since no one, no matter how ignorant, would be so ill-mannered as to dare criticize the Redeemer and those who spoke in his spirit, thus he should likewise refrain from criticizing Boethius as author, and myself as his faithful interpreter. ${ }^{13}$

The wording of this paragraph is a bit obscure, even in Spanish. The key is the phrase, escrebir cosa trobada (to write a thing in verse), the meaning of which, in addition to the statement on the cover, 'the prose is metered', is made clear when one finds that the Spanish of Aguayo's translation is written in octosyllables, but in prose; a rhythmic technique that, according to Aguayo himself, was directly inspired by the words of the Scriptures and, moreover, by the style of the Savior himself. This artifice was seen as a 'unique extravagance' by Menéndez Pelayo. ${ }^{14}$ Pellicer believed that Aguayo's argument was an exaggeration: the Canticle of Moses, the Psalms of David, the Proverbs, the Song of Solomon and the Books of the Prophets, 'were authentic poetry, although we are unfamiliar with the meter' (he was quoting Robert Lowth, De sacra poesi

'[la] había vuelto de latín en castellano, no palabra por palabra, mas sentencia de sentencia; no tirando alguna suya ni poniendo cosa mía, porque en trasladar los libros no se han de dar las palabras por cuenta, mas las sentencias por peso'; 'E si alguno juzgare por liviandad escrebir cosa trovada, porque mucho reprehenden las cosas que menos se saben, sepa que en esta manera escribió y habló Moisén, David, Salomón y muchos de los Prophetas; y muchos Sanctos del Nuevo Testamento, y aun el Señor de unos y otros no aborreció este modo de hablar cuando dijo: Heli, heli, lamma sabacthani! y en otro lugar: Non dico tibi septies, sed usque septuagies septies. E como ninguno, por ignorante que sea, será tan descomedido que ose reprehender al Redentor y a los que por su espíritu hablaron, detenerse ha en reprehender a Boecio como auctor, y a mí como su fiel intérprete'. Severin Boethius, La consolación de la filosofía, (trans.) Fray Alberto de Aguayo, (ed.) F. Luis G. Alonso Getino (Buenos Aires: Espasa-Calpe, 1943), 'Argumento en todo el libro', pp. 43-44.

Marcelino Menéndez Pelayo, Biblioteca de traductores españoles, in Edición nacional de las obras completas de Menéndez Pelayo (Santander: Csic, 1952-53), vol. 54, p. 36. 
hebraeorum, Oxford, 1753) ${ }^{15}$ Aguayo's Boethius, however, reached a notable level of prestige as a model for translation, and was explicitly cited by Ambrosio de Morales (1513-91) in his Discurso sobre la lengua castellana, where he said that Boethius' text was 'better in our language than in Latin.'. ${ }^{16}$ Juan de Valdés (1509-41) was equally full of praise, citing Aguayo's translation in his Diálogo de la lengua. ${ }^{17}$ According to Menéndez Pelayo, Morales and Valdés praised this translation because they had not actually discovered its extravagant artifice; an interesting argument, since it has to do with the debate about the right style for speaking in prose and in verse; a crucial subject, which ultimately alludes to the ability to use the style and register best suited to each situation.

At this point the issue of translation is directly linked to the long process of constructing modern standard Spanish. The Diálogo de la Lengua by Juan de Valdés (who was also, as we will see, a translator of the Bible) is, as is widely acknowledged, one of the most important works in the history of the Spanish language. It is a book that took part in a secular controversy over how to construct a model for Spanish that could properly account for all its different registers. The history of this controversy is long and of great importance for the history of Spanish literature and aesthetics and, although it largely unfolds around the discussion of Greco-Roman and Italian models, the Bible also constitutes an important point of reference. The latter shows up in a variety of contexts. We might recall, for example, the case of Fray Pedro Malón de Chaide (1530-89), who criticized poetry but, at the same time, pointed to some examples from the Bible as poetic models. For instance, King David, who 'composed sad dirges and ballads, not about when Alonso de Aguilar died in the Sierra Nevada, Granada, nor about the people of Zamora, but rather about when Saul and his children died in the Mountains of Gilboa, and ordered they be sung in Israel just as the old ballads of Castile are sung today'. Also, Moses and Job, part of whose book 'is written in hexameter', Jeremiah, who 'composed dirges and sad songs upon the death of the glorious king Josiah', and many more songs and the like that 'in the Scriptures the Holy Spirit said in verse', in addition to the saints and Church Fathers. ${ }^{18}$ We must not forget the polemical context in

15 'eran auténtica prosa, aunque se ignoraba su versificación'; Pellicer, Ensayo de una Bibliotheca, p. 5 .

16 'mejor en nuestra lengua que en la latina'; Ambrosio de Morales, 'Discurso sobre la lengua castellana', in Las obras del maestro Fernán Pérez de Oliva (Madrid: Benito Cano, 1787), vol. 1, p. xliii.

17 Juan de Valdés, Diálogo de la lengua, 4th ed. (Madrid: Espasa Calpe, 1964), p. 121.

18 'hizo endechas tristes y romances, no de quando don Alonso de Aguilar murió en Sierra Nevada, ni de los zamoranos, sino de cuando Saúl y sus hijos murieron en los montes de Gelboé, y mandó que se cantassen en Israel como agora se cantan los romances viejos de 
which Malón de Chaide was writing, in the vein of Fray Luis de León. As such, he felt obliged to defend his biblical translation using the well-known argument that, ultimately, God had revealed his word in the vernacular language of the Hebrews, 'which was spoken by the shoemaker and the tailor and the weaver and the digger and the shepherd and the masses as a whole', and that the great Greeks and Romans had, as it were, written in 'their own Spanish', in other words in their own vernacular. Thus, in terms of purity and expressiveness, Spanish was by no means inferior to Greek or to Latin, languages into which the Bible had indeed been translated. ${ }^{19}$

Alongside Malón de Chaide there were other authors pondering over the right Spanish meter to match the meters of biblical poetry. Juan de Pineda (d. 1593?), author of Diálogos familiares de agricultura cristiana (Familiar Dialogues of Christian Agriculture), equated 'theology' with 'poetry', insofar as both operate 'by riddles and symbols and obscure parables, which conceal a great deal more that what meets the eye', a fundamental characteristic of the theological language spoken by the sages, all the more so if they were poets since poetry 'requires divine inspiration'. In Spanish, the meters that could match the grandiose language of great poets like Homer, Ovid or Virgil were 'our Spanish coplas de arte mayor, which we have so unjustly banished and forgotten, replacing them with Italian forms just because they come from overseas. ${ }^{20}$

What this example reveals is how the use of the Bible as a poetic model fits within a broader debate over the Spanish language, alongside the debate over classical models as well as the adoption of Italian meters. At a certain point, the allusion to the biblical literary models personified by Moses and David turned into an argument used by those seeking to defend the merit of traditional Spanish meter and poetics, since to equate it with Hebrew, Greek and Latin was indeed to defend its own merit in the face of other foreign-based

Castilla'; 'está escrito en verso exámetro'; 'hizo endechas y canciones tristes a la muerte del glorioso rey Josías'; 'el Espíritu Santo dixo en la Escritura en verso'; Pedro Malón de Chaide, Libro de la conversión de la Magdalena, en que se ponen los tres estados que tuvo de pecadora, penitente y de gracia [1588] (Alcalá de Henares: Justo Sánchez Crespo, 1603), fols. $6 \mathrm{v}-7 \mathrm{r}$.

'en que hablaba el çapatero y el sastre y el texedor y el cavatierra y el pastor y todo el vulgo entero'; 'su Castellano'; Malón de Chaide, Magdalena, fols. 16v-17r.

'por enigmas y símbolos o parábolas escuras, que encubren muy otras cosas de lo que representa en la corteza de la letra'; 'pide aflato divino'; 'nuestras coplas castellanas de arte mayor, tan desterradas y olvidadas de nosotros contra razón, aviendo admitido en su lugar las italianas, porque vienen de ultramar'; Juan de Pineda, Diálogos familiares de agricultura cristiana, Biblioteca de Autores Españoles (Madrid: Atlas, 1963), vol. 1, pp. 71-72. 
models. ${ }^{21}$ In essence this is the same argument that was used to defend vernacular translations of the Bible, for example that Spanish was similar to Hebrew in that both were vernacular languages.

The debates surrounding the Spanish language became particularly intense in the seventeenth century, especially starting with the controversy ignited by the poetry of Luis de Góngora (1561-1627). One of Góngora's friends was Pedro de Valencia (1555-1620), the author of an extremely important document for the history of Spanish literature, namely a letter to Góngora commenting on his Soledades, which the poet of Cordoba had sent to the humanist in order to receive his critical opinion. At one point, when advising Góngora on which poetic models should be imitated, Pedro de Valencia says, 'I pray to God that I might be able to convey to you what it is to read those mighty ones, and others greater still: David, Isaiah, Jeremiah and the other prophets, what they sound like with their own properties, allusions and metaphors in the original Hebrew and Greek.'22 The examples of Pedro Malón de Chaide and Pedro de Valencia bring us face to face with two key moments in the reception and study of the Bible in early modern Spain: Malón was a disciple of Fray Luis de León in Salamanca, whereas Pedro de Valencia was a disciple of Benito Arias Montano.

Pedro de Valencia's letter to Góngora is, as we have said, an important text within one of the most famed stylistic and prescriptive controversies in the history of Spanish literature, which revolved around the Cordoban's poetry. It is an extremely harsh and prolific controversy that returns to the age-old problem of the expressive features of Spanish and the construction of a poetic model based, for instance, on the opposition between clarity and obscurity. ${ }^{23}$ One of the leading figures in this controversy was the Spanish playwright and poet Félix Lope de Vega (1562-1635), who defended, in a variety of ways, what could be called a poetics of simplicity or clarity against the obscurity of Góngora's school. One of the greatest examples of this brand of poetry can be found in his poem El Isidro, dedicated to a medieval saint from Madrid, St

21 Rogelio Reyes Cano, 'Aspectos de la relación de Cristóbal de Castillejo con la literatura italiana', Revista de Filología Italiana, 7 (2000), pp. 218-19.

22 'Pluguiera a Dios i yo pudiera communicarle a V.M. la lección de aquellos grandaços i de otros mui mayores, David, Isaías, Jeremías i los demás prophetas, cómo suena con sus propiedades, allusiones i translaciones en sus lenguas originales hebrea i griega'; Pedro de Valencia, Epistolario, (ed.) Francisco J. Fuente and Juan F. Domínguez (Madrid: Clásicas, 2012), p. 275.

23 Joaquín Roses Lozano, Una poética de la oscuridad. La recepción crítica de las Soledades en el siglo XVII (London, Madrid: Támesis, 1994). I have chosen this reference, from among the vast literature on this controversy, precisely because it discusses the problem of 'obscurity'. 
Isidore. Apart from wanting to dedicate a piece to the saint of his home town, Lope approaches this poem as a theory of poetry, contrasting the models of two different saints by the same name. On the one hand, Isidore of Seville, the great saint of the Visigothic period, archbishop of Seville, wide-ranging author and universal sage. On the other, Isidore of Madrid, the uneducated farm laborer saint ('Over there a golden crosier, / here a rough wrought-iron plough; / over there a cloak, here a coat, / brocade there, here the pick, / souls there, here cattle ... he knew not letters, nor whom / to ask about them, / and if once he heard an $\mathrm{ABC}$, / all he learned was the Christ' cross $^{24}$ / but it suited him just fine'). ${ }^{25}$ This juxtaposition of two types of sainthood is also a juxtaposition of two theories of poetry. Thus it was possible, to a certain extent, to sing the life of a poor, humble saint from Madrid via a counter-epic poem ('Canto el varón celebrado / sin armas, letras ni amor'. I sing the man celebrated / without weapons, letters or love), written in humble Spanish quintilla verse (five-line stanzas with eight syllables per verse): 'If one should object / of so many who are shrewd / that you are humble and plain, / say that they are Spanish / both the verses and their subject'; 'To those who would be fooled by wit / with strange style and tongue / oh Spanish muse tell them that / it is Spain that they are from'). ${ }^{26}$ Whereas the simplicity of the style and meter are a sign of the Spanish language, the poetic form imitates the classical and biblical model: '... these short bits of praise, which I hope will increase many people's devotion to God, which, since they are in verse, would seem to move them more effectively'. Ultimately Virgil himself held that God had created verse, and Moses, David, Solomon, Job and the Prophets had written in verse ('proof that the church honors its holidays with verse is the fact that the lives of the saints are written thus'). ${ }^{27}$ The fitting comparison between the humble verses of Spanish

24 'Cristus' was the cross put at the beginning of the children's notebooks.

25 'Allí ay báculo dorado, / aquí arado tosco herrado; / allí ay capa, aquí capote, / brocado allí, aquí picote, / almas allí, aquí ganado'; Isidore of Madrid 'no supo letras, ni a quien / preguntárselas también, / que un abecé que oyó, / sólo el Christus aprendió / pero éste súpole bien'; Félix Lope de Vega, Isidro. Poema castellano (Barcelona: Iusepe Andrés, 16o8), fols. 9r-10r.

26 'Si os pusiere por ogjeto / de tantos algún discreto, / que soys humildes y llanos, / dezid que son castellanos / los versos como el sugeto'; 'A quantos su ingenio engaña / con estilo y lengua extraña / musa española dezildes / son naturales de España'; Lope, Isidro, fols. $1 \mathrm{v}-2 \mathrm{r}$.

'... estas cortas alabanças, que espero en Dios aumentarán la devoción en muchos, que por ser en verso, parece que mueven con mayor eficacia'; 'el honrar la iglesia sus fiestas con versos acredita mucho que en ellos se escrivan las vidas de los santos'; Lope, Isidro, 'Prólogo'. 
as opposed to other foreign meters, particularly those coming from Italy, brings us back to the controversy discussed above in relation to Diálogos familiares de agricultura cristiana by Juan de Pineda. The choice of poetic genre together with the focus on sacred history led Lope de Vega to call his own Isidro and his modest quintillas a 'Castilian Psalter'.28 It is not by chance that in the poem that the Marquis of Sarriá dedicates to Lope at the outset of Isidro, he calls him 'sacred historian' ('and because he raised him up [Isidore, to the heavens] / you are now a sacred historian, / Isidro more respected, / and you closer to God'). ${ }^{29}$ Casting Lope de Vega as a 'sacred historian' hearkens back to what Lope himself wrote about Mateo Alemán (1547-1614) at the outset of the latter's San Antonio de Padua. There, he likewise called Alemán a 'sacred historian', a play on the name Mateo Alemán and that of Matthew the Evangelist, thereby casting St Anthony was a 'new Christ'. ${ }^{30}$

The significant biblical inspiration of Mateo Alemán's work has already been noted: ${ }^{31}$ his heavy use of the Old and New Testament and of St Paul, his knowledge of the work of Arias Montano, the constant presence of the book of Job in his own work. At one point he even explicitly states his admiration for the commentaries by Father Juan de Pineda $\left(155^{8-1637}\right.$, not to be confused with the Juan de Pineda mentioned above, author of the Diálogos familiares) to the book of Job, in a piece that he wrote in praise of the same. ${ }^{32}$ Although the meaning of these words of praise can be debated, it is clear that Father Pineda's Book of Job is a remarkable book that was well known in Spain during this period. At the beginning of the first book, Pineda confronts the opinions of heretics, Lutherans and Anabaptists, who thought the book of Job could be understood as a parable, and not as a historical text (vera historia, 'true history'). One of the reasons for this allegorical interpretation was that the book was written in verse, carmine, like the Song of Songs, which was a kind of pastoral tale. By contrast, Pineda thought that Job himself was the

28 Lope de Vega, 'Égloga a Claudio', in Rimas humanas y otros versos, (ed.) Antonio Carreño (Barcelona: Crítica, 1998), p. 707.

29 'y por haberle subido [a Isidro a los cielos] / queda historiador sagrado, / Isidro más estimado, / y vos a Dios parecido'. Lope, Isidro.

$30 \quad$ Mateo Alemán, S. Antonio de Padua (Valencia: Patricia Mey, 1607).

31 Michèle Estela-Guillemont, 'Referencias bíblicas en la obra de Mateo Alemán', in La Biblia en la literatura del Siglo de Oro, (ed.) Ignacio Arellano and Ruth Fine (Madrid, Frankfurt am Main: Iberoamericana, Vervuert, 2010), pp. 117-34.

Estela-Guillemont, 'Referencias bíblicas', p. 119. 
author of the book, and that he had written it in verse, like other books of the Bible, according to the Hebrew meters. ${ }^{33}$

A book of history or a book of poetry? The debate around the style of the Book of Job situates the problem of literal or allegorical interpretation in the realm of literary genres. One of the most noteworthy examples of how the problem of exegesis was approached via literary genre is Jerónimo de San Pedro's Cavallería celestial (Celestial Chivalry). ${ }^{34}$ The book, published in 1554, is an account of the Bible, but in the style of a chivalric romance. Although it is not an isolated case, it is the most striking of a series of works referred to as novelas de caballerías a lo divino (divinized chivalric romances). It is, in any case, a uniquely bold book, in which the characters of the Bible are transformed into characters of chivalry (for example, Christ is the Knight of the Lion). The text is organized into several layers. In the first place, the narrative reproduces the literal or historical meaning of the Bible. In order to add in the other levels of exegesis, Jerónimo de San Pedro introduces four more characters, who appear throughout the narration to clarify the different meanings of the Bible: allegorical, moral, anagogical and tropological. These characters are Master Anagógino, Tropología the Wise, and, most importantly, 'el sabio Alegorín' (Alegorín the Wise) ${ }^{35}$ (whose name recalls that of 'Merlin the Wise', as the Arthurian wizard was known in Spain), as well as the damsel Moraliza. So, for example, when Adam falls into sin, Alegorín the Wise comes over to him to tell him that he looks beautiful, since he is the prefiguration of Christ who, like Adam, was also created without the intercourse of man. Moraliza, on the other hand, comes to him and finds him repulsive, because to her mind Adam represents the seven deadly sins. ${ }^{36}$ The book, which in essence was a Bible in the Romance vernacular, was banned by the Inquisition. ${ }^{37}$ It is important to bear in mind the long-standing and commonplace opposition between on the

33 Juan de Pineda, Commentariorum in Iob libri tredicim (Seville: Colegio de San Hermenegildo, 1598), 'Praefatio', ch. I, 'Sit ne vera historia Iob an vero parabola?' (Is Job a true story, or in fact a parable?), ii; ch. IV, 'Qua lingua et quo dicendi stilo scriptus liber iste fuerit' (In what language and in what style this book was written), fol. $\mathrm{x}$. Jerónimo de San Pedro, Libro de Cavallería Celestial del pie de la Rosa fragante (Antwerp: Martín Nucio, 1554).

Recall how the figure of 'Alegorín the Wise' shows up in the accusations in the trial of Fray Luis de León.

36 San Pedro, Libro de Cavallería, pp. 33-35.

37 Donatella Gagliardi, 'Bons et mauvais livres dans l'Espagne du Xvi siècle. La censure de la Caballería celestial (1554)', in Les voies du silence dans l'Espagne des Habsbourg, (ed.) Alexandra Merle and Araceli Guillaume-Alonso (Paris: Presses de l'université Paris Sorbonne, 2013), pp. 149-65. 
one hand chivalric literature, considered to be the prototype of profane writing, and on the other sacred literature. One need look no further than the example of St Teresa of Ávila herself in her autobiography. This must then lend added significance to this narrative account of the devices of biblical exegesis, starting with this sudden appearance of allegory in the middle of the literal course of history: Alegorín the Wise teaches that allegory basically amounts to the way in which the Old Testament prefigures the New Testament and the life of Christ. Allegory is, then, fundamentally Christological, and is ultimately about the way in which nature represents the sacred order. One of the many ways in which the difference between the old law and the new was articulated was precisely around the issue of representation. Thus, representations in the Old Testament were just incomplete figures, sketches that needed to be polished in order to create the perfect image of salvation. ${ }^{38}$

\section{From Literalness to Allegory: The Problem of Representation}

The system of biblical exegesis, and the tension between literalness and allegory, is also the key to understanding any given story. This model of Bible interpretation had already been expressed by Erasmus, for example, who said that (here in a later English translation) 'The same thing must be observed and kept in all manner of learning which include in themselves a plain sense and a mystery, even as they were made of a body and a soul, that the literal sense little regarded thou shouldest look chiefly to the mystery. Of which manner are the letters of all poets and philosophers, chiefly the followers of Plato. But most of all, holy scripture, which being in a manner like to Silenus of Alcibiades, under a rude and foolish covering include pure divine and godly things.' ${ }^{39}$ This passage by Erasmus gives us a hint at how exegetical tools which arose in order to interpret the Bible (especially based on the literal/allegorical opposition) were then used to interpret other stories or texts. An obvious example is that of

38 Sor Juana Inés de la Cruz (1651-95), Neptuno alegórico, (ed.) Vincent Martin (Madrid: Cátedra, 2009), p. 76: 'And thus nothing ever looks very distinguished (even in the sacred texts) unless it is first preceded, as in drawing, by a number of figures representing it'; ( $\mathrm{Y}$ así ninguna cosa vemos muy insigne - aun en las sagradas letras - a quien no hayan precedido diversas figuras que como en dibujo las representen).

39 Erasmus, Enchiridion Militis Christiani / The Manual of the Christian Knight (London: Methuen and Company, 1905), p. 145; see also Cristóbal de Villalón, El Crótalon, (ed.) Asunción Rallo (Madrid: Cátedra, 1990), pp. 25-26. As noted by the editor, Villalón puts this idea into practice by using biblical references side by side with profane ones, such as Ariosto. 
classical mythology, which, as fable, was understood essentially through literal interpretation and allegorical interpretation, and also through its tropological, anagogical and natural meanings. ${ }^{40}$ Another fertile ground for employing this reinterpretation of the classical tradition is, for example, the integration of the sibyls into the realm of the Christian prophets. ${ }^{41}$

Biblical exegesis comes down to a battlefield over meaning. The issue of literalism gives rise to the problem of the relationship between words and things. For example, as Juan de Pineda wrote,

any interpreter of the Holy Scripture must first secure its true literal meaning, and then upon this place its mystical meaning, which, it should be said, is divided into the moral, the allegorical and the analogous. For, as the mystical is true insomuch as it is founded on literal truth, if the literal is not correct, the mystical will be even less so. This, as opposed to what some do, who, in order to fit in a moral meaning for a doctrine that suits their purpose, do not hesitate to falsify the literal meaning, and, to the extent that they are able to, strip the Scripture of the power to prove what is true or rebuke that which is false. As for mystical meanings, be aware of what was already touched upon with Hugh of St Victor and with St Thomas and others, that they are not signified by the words of the Scripture, but rather by the things signified by the words, by the similarities that such things have with those that are signified thereof. ${ }^{42}$

Which is to say that the literal meaning refers not to the words of the Scripture, but rather to the things signified by those words. This matter is crucial from the perspective of grammar and logic. In Grammatica audax (Daring Grammar), by Juan Caramuel (1606-82), these issues form the basis of a theory of meaning and communication, based on the fundamental problem of the relationship between words and things. Do words have a natural meaning, or are they arbitrary signifiers? This is only normal for a philosophy that was obsessed with this subject, and which saw in ancient, non-European languages, an

40 Juan Pérez de Moya (1513-97), Philosophía secreta, (ed.) Carlos Clavería (Madrid: Cátedra, 1995), p. 69: 'De los sentidos que se pueden dar a una fábula' (On the meanings that can be given to a fable). María Tausiet, 'Introducción', in Alegorías. Imagen y discurso en la España Moderna (Madrid: Csic, 2014), pp. 20-21.

41 Pedro Mexía, Silva de varia lección, (ed.) Antonio Castro (Madrid: Cátedra, 1989-90), vol. 2, pp. 256-72; David S. Katz, 'Vossius and the English Biblical Critics', in Scepticism and Irreligion in the Seventeenth and Eighteenth Centuries, (ed.) Richard H. Popkin and Arjo Vanderjagt (Leiden: Brill, 1993), pp. 142-84, esp. p. 161.

Pineda, Diálogos familiares, p. 130. 
opportunity to reflect on the problem of the semantic ambiguity of words. In fact, for the problem of natural meaning, Caramuel takes as his point of departure both Chinese ('the Chinese do not make use of their lips, but rather focus on adorning their writing system; they have but a few simple characters, with which they compose their Politici, numbering nearly forty thousand'), ${ }^{43}$ and Hebrew ('in the Hebrew language I have observed a syntax that is worthy of admiration. Twenty-two letters are used, which have different artificially imposed meanings that are, however, analogous because of the way they are pronounced. All of the prepositions must be made up of these twenty-two meanings'), ${ }^{44}$ in order to demonstrate the arbitrariness of the meanings of words. Based on this arbitrariness, Caramuel describes meaning as a transubstanciación moral (moral transubstantiation); just as in the Sacrament of the Eucharist the bread ceases to exist as such in the presece of Christ, words cease to be mere segments of air, transforming into their different meanings. This is how he explains, for example, why the words Jesus, Mary or the names of the saints are the subject of religious worship. The words are no longer 'segments of air', but rather virtually become Jesus, Mary or the saints. The same is true of the sign of the cross. In both cases, 'moral transubstantiation' justifies adoration of Christ, the Virgin Mary and the Saints. ${ }^{45}$ We have to keep in mind, also, that the philosophy of language of Port Royal, for example, was deeply based upon the same Eucharistic model as that of Caramuel. In fact, as Louis Marin has studied, 'It is not surprising that the exact starting point of our research was a paper on the theories of Bible translation at Port-Royal ... What problems are posed by the very translatability of a text inspired by God?'46 It was, thus, a model of representation based upon the dialectics between literalism and underlying meaning that emerged from the translation of the Bible. ${ }^{47}$

43 los chinos no se sirven de los labios, sino que se esfuerzan en adornar su ortografía, tienen pocos caracteres simples, con los cuales se componen los Politici que son casi quarenta mil'; Juan Caramuel, Gramática audaz, (trans.) Pedro Arias (Pamplona: EunsA, 200o), p. 16.

44 'en la lengua hebrea he observado una sintaxis digna de admiración. Se usan veintidós letras que tienen significados diferentes, artificialmente impuestos, pero análogos por los recursos de pronunciación. Todas las proposiciones deben componerse con estos veintidós significados'; Caramuel, Gramática, p. 15.

45 Caramuel, Gramática, p. 24.

46 Louis Marin, La critique du discours. Sur la 'Logique de Port-Royal' et les 'Pensées' de Pascal (Paris: Minuit, 1975), pp. 10-11. For an illuminating analysis of the alegorical potential of Eucharist in Spanish Baroque, see Fernando Rodríguez de la Flor, Mundo simbólico. Poética, política y teúrgia en el Barroco hispano (Madrid: Akal, 2012), pp. 137-67.

47 It is worth remarking that Caramuel was strongly engaged against Jansenists in the great seventeenth-century debates on Probabilism. Dino Pastine, Juan Caramuel, probabilismo 
Of course, this relationship between allegory, representation and Eucharist is made explicit in a very unique way in the auto sacramentales (sacrament plays). The work of Calderón de la Barca (1600-81) attests to the complexity of the concept of representation in the seventeenth century, which was based largely on this Eucharistic model. Calderón's definition of the term 'allegory' is well known: 'Allegory is nothing more / than a mirror which translates / that which is into that which is not; / and all of its elegance resides / in making the copy look / so similar in the picture, / that the person who sees it / thinks he is seeing both at once. ${ }^{48}$ It is no coincidence that this definition comes from a play based on an extreme Eucharistic allegory, wherein the fabled god Pan is transformed into Pan the true god. The fable/truth opposition is illustrated in a remarkable 'Loa para el auto de El verdadero dios Pan' (Prelude to the play The true god Pan), ${ }^{49}$ where the characters History, Poetry, Music and Fable appear in order to explain the tensions between them when constructing the allegory of the Eucharist. As explained by the editor of the play, Fausta Antonucci, Calderón appears to share the opinion that the Gentile, Greek and Roman poets were familiar with the Bible, and that they had copied and corrupted it in order to support their own mythology. As explained by Baltasar de Vitoria in his Teatro de los dioses de la gentilidad (Theater of the Gentile Gods) (a book published in 1620-23, that Calderón may have been familiar with), 'it is a known fact that the ancient philosophers and poets were the theologians of the ancient Gentiles ..., and thus the majority of the poets endeavored to take advantage of the books of the most wise Moses, and of all the rest who had played a part in the holy scripture, picking it apart so as to adorn their fables' ${ }^{\prime} 0$ It is clearly the most extreme way of integrating the classical world into the model of biblical interpretation, upholding, on the one hand, the identification of poetry with theology in the ancient world, and on the other reducing the two of them to allegory as an interpretive model. In fact, it is no longer just

ed enciclopedia (Florence: La Nuova Italia Editrice, 1975).

48 'La alegoría no es más / que un espejo que traslada / lo que es en lo que no es; / y está toda su elegancia / en que salga parecida / tanto la copia en la tabla, / que el que está mirando una /piense que está viendo a entrambas'; Pedro Calderón de la Barca, El verdadero dios Pan, (ed.) Fausta Antonucci (Pamplona, Kassel: Universidad de Navarra, Reichenberger, 2005) pp. 160-61.

$5^{0}$ 'sabida cosa es que los filósofos y poetas antiguos fueron los teólogos de la antigua gentilidad ... y así los más de los poetas procuraron aprovecharse de los libros del sapientísimo Moysés, y de los demás que tocaban a la sagrada escritura, sacándola de sus quicios para adorno de sus fábulas'; Fausta Antonucci, 'Introducción' to Calderón, El verdadero dios, p. 23. 
an interpretation of texts themselves, but rather of the whole of human history, by identifying a primordial or original wisdom that foresaw Christian theology.

\section{Polemics Surrounding the Translation and Interpretation of the Bible}

The discussions about the Bible as a literary and linguistic model, or the construction of a system of representation, are processes that can only be understood in conjunction with the major conflicts that had placed people's relationship with Scripture at the heart of the criteria for defining orthodoxy and heterodoxy. Interpreting the Bible and translating it into the vernacular languages are two of the main battlefields in the struggle for religious authority. The aforementioned case of Juan de Valdés is a good example of the shape these conflicts took. Valdés was more than just one of the principal theorists of the Spanish language. He was also one of the most complex and elusive religious reformers of the first half of the sixteenth century. In addition, he was a translator of part of the Bible. In the introduction to his translation of Psalms, addressed to Giulia de Gonzaga, Valdés begins the explanation of his translation method with the problem of literalism:

and since I thought that in order to make you quite pious, it would be of much service to you to read the Psalms of David, I have rendered them into the Spanish vernacular, extracting them from the Hebrew writing nearly word for word, as much as the Spanish manner of speech could bear. And I have maligned the Spanish on more occasions, by speaking strangely, than I have the Hebrew, by altering it. I have acted thus, thinking it to be befitting and just for those things written with the Holy Spirit to be treated with the utmost respect. Of what is mine, I have mixed in some words so as to make the writing shine, and make it clearer and more delectable. In order to make these words known, they are written in red ink, as an attempt to give due credit to the words of man, differentiating between these words, and those that are of the Holy Spirit. It is quite true that, for the most part, the words written herein with red ink are to be inferred from the Hebrew writing. ${ }^{51}$

$51 \quad$ 'y pareziéndome que que para hazeros muy pía os servirá mucho la lición de los Salmos de David, os los he puesto en romance castellano, sacándolos de la letra hebrea, casy palabra, en quanto lo ha sufrido el hablar castellano. Y aun me he atreuido más vezes a la lengua castellana, hablando impropiamente, que a la hebrea, alterándola. Esto he hecho 
As is pointed out by the editor of this translation, Domingo Ricart, ${ }^{52}$ the introduction to the translation of the Psalter can be considered to be a version of number 54 in Le cento e dieci divine considerazioni, which states 'that prayer and consideration are two sure books or interpreters for understanding the Holy Scripture, and how man should make use of them'. In this respect, it is also worth mentioning consideration number 55, 'against curiosity and how one should read the Holy Scripture without curiosity'. Curiosity (la curiosità de carne, curiosity of the flesh) is taken to be a harmful quality, typical of those who 'read the Holy Scripture for the sole purpose of knowing and interpreting', as opposed to a pious reader, who

should only expect the knowledge and internal feelings that God, by means of his Holy Spirit, shall give unto his soul, and knowledge of the things of the Holy Spirit that he, by means of those feelings, will come to experience; and in this way, when taking in hand a book of the Holy Scripture, he should expect to interpret that which passes through him. ${ }^{53}$

As has already been pointed out, despite the fact that many of Valdés' choices as translator can be explained through an automatic use of language or through the traditions that preceded him, in the end 'it is no less evident that for him, literalness is superior to any theoretical notion. ${ }^{54}$ So, here we have a relationship between literalism, inspiration from the Holy Spirit, experience, and

assy, pareciéndome cosa conueniente y justa que las cosas escrittas con Espíritu Santto, sean tratadas con mucho respeto. He mezclado del mío algunas palabras a fin que la letra lleue más lustre, vaya más clara y más sabrosa. Estas, porque sean conocidas, van escrittas con tinta colorada, pretendiendo que se les ha de dar el crédito que se deue dar à palabras de hombre, haziendo diferencia entre ellas y las que son de Spíritu Santto. Es bien verdad que, por la mayor parte, las palabras que van escrittas con tinta colorada se entienden de suyo en la letra hebrea'; Juan de Valdés, Diálogo de doctrina christiana y El Salterio traducido del hebreo en romance castellano, (ed.) Domingo Ricart (Mexico: UnAM, 1964), p. 135.

$5^{2}$ Valdés, Diálogo de doctrina, p. 12.

53 'Che la orazione e la considerazione sono dui libri o interpreti per intendere la santa scrittura molto certi, e come l'uomo si deve servire di essi'; 'Contra la curiosità e come si deve leggere la santa scrittura senza curiosità'; 'leggono la santa scrittura solamente per sapere e per intendere'; 'deve solamente pretendere li conoscimenti e li sentimenti interiori che Dio per mezzo del suo spirito santo gli darà nell'anima, e quelli che egli mediante essi andrà esperimentando delle cose dello spirito santo; di manera que, pigliando in mano un libro della santa scrittura, pretenda intendere quello que é passato per lui'; Juan de Valdés, Le cento e dieci divine considerazioni (Halle: G. Ploetz, 186o), pp. 184-91.

54 Margherita Morreale, 'Juan de Valdés traducteur de la Bible. Théorie et pratique à travers la version du psaume 17 (18)', in L'Humanisme dans les lettres espagnoles. XIX ${ }^{e}$ Colloque 
understanding of Scripture. In his introduction to the Psalms, he insists that there is a level of literal reading, wherein the translation must adapt to the Hebrew text, and another level that refers to the spirit of the text, 'so as to read it as Christian and not as Hebrew'. This reference clearly alludes to the prophetic and symbolic character of the kingdom of David as a prefiguration of that of Christ ('and keeping this in mind, you go about confirming in Christ that which you shall read in David; while also keeping about you, in some Psalms, three goals: one, the figure of David, another, that of Christ, and the other, sometimes that of you yourself, and other times that of the Christian church'). ${ }^{55}$ In this sense, the 'reading of the Scriptures' would be the specifically Hebrew way of knowledge, inferior to knowledge through Christ, specific to Christians. Furthermore, for Valdés, the practice of translation involves a path of gradual introduction to the Scriptures, in parallel to the spiritual process.

In the case of Valdés there is, it seems, a relationship between access to religious truth, the hierarchical reading and translation of the books of the Bible, and, finally, progress in the circle of believers around Juan de Valdés, and their sense of intimate connection and friendship. ${ }^{56}$ In the midst of a hostile environment, dissimulation is a means of protection, but also a pedagogical method and a practical reflection of that intimate and complete 'freedom of spirit' that inspires the 'Christian enterprise. 57

This relationship between the interpretation of the Bible and the creation of a group of 'believers' may also be seen, to a certain extent, in the case of the most important Spanish Bible scholar, Benito Arias Montano (1527-98). Indeed, in the proceedings against one of his most noteworthy disciples, Fray José de Sigüenza (1544-1606), the accusation was based on several issues related to the interpretation of the Bible, and to the special relation that Arias Montano had developed with his disciples. Thus, the statements under scrutiny were, among others, the following: 'that one should only preach the bare Gospel and construe it literally, for that is all there is'; 'that the Saints often speak their own mind instead of the literal meaning'; 'that since St Paul wrote his Epistles to converted Jews and Gentiles and they understood them

international d'études humanistes, Tours, 5-17 juillet 1976, (ed.) Agustín Redondo (Paris: Librairie Philosophique J. Vrin, 1979), pp. 65-88, p. 74.

'Para leerla como christiana y no como hebrea', 'y que llevando esto en la memoria, vais verificando en Christo lo que leeréis en David; llevando también en algunos Salmos tres intentos: el uno, a la persona de David, el otro, a la de Christo, y el otro, unas vezes a la vuestra, y otras vezes a la de la yglesia christiana'; Valdés, Diálogo de doctrina, p. 139.

56 Lucca Addante, Eretici e libertini nel Cinquecento italiano (Rome, Bari: Laterza, 2010).

57 Massimo Firpo, Entre alumbradosy 'espirituales' (Madrid: FUE, 200o), p. 64. 
without glosses, we should also understand, I mean imagine, that he wrote them for us, and we have no need for them to be glossed'; 'that as long as they leave him Arias Montano and a Bible, he does not care at all if they take away the rest of the books in his cell. That the person who has best understood the Bible is Arias Montano and that he appears to prefer him to the Saints; and that he said that God revealed the Holy Scripture to him.'.58 Of course, these statements must be understood in the context of an accusation made within a restricted circle, many of whose members saw Arias Montano's group as a small cult. In fact, during the proceedings a great deal of attention is given to the cult-like nature of this group, gathered around the revered teachings of the master. A witness to the proceedings, friar Antonio de León, refers to 'a way of speaking that he has heard friar José de Sigüenza use, and which everyone says comes originally from Arias Montano, namely mysterium regni Dei (the mystery of God's Kingdom)'. José de Sigüenza had told him on various occasions

that the literal and moral meaning of Scripture is for everyone; and this witness believes that the mysterium regni Dei, as they say, must likewise not lie in the spiritual and mystical, so typical of the Saints, for said friar José says that the Saints sometimes speak their own thoughts, but not those of the one they claim as the author; from which this witness gathers that this mysterium regni Dei is either another anagoric [sic] meaning, or a literal one that is different from that which is commonly received by the Saints ... Item this witness says that in order to communicate this mystery ... they ask for the disciples to adopt some sort of attitude. ${ }^{59}$

$5^{8}$ 'que no se ha de predicar sino el Evangelio desnudo y construir la letra, que allí está todo'; 'que los Santos dicen muchas veces sus pensamientos, que no el sentido literal'; 'que como San Pablo escribió sus Epístolas a los que se habían convertido del judaísmo o gentilidad y las entendían sin glosas, así hemos de entender, digo imaginar, que nos las escribió a nosotros, y no tenemos necesidad de su desglose'; 'que como le dejen a Arias Montano y una Biblia, no se le da le quiten los libros de la celda. Que el que mejor ha entendido la Biblia es Arias Montano y que parece le antepone a los Santos; y que ha dicho que Dios le reveló la Sagrada Escritura'; Gregorio de Andrés, Proceso inquisitorial del Padre Sigüenza (Madrid: FUE, 1975), p. 79 .

59 'un modo de hablar que ha oído de fray José de Sigüenza y todos dicen que nace de Arias Montano, y es mysterium regni Dei'; 'que el sentido literal y moral de la Escritura es para todos; y le parece a este testigo que el mysterium regni Dei, que ellos dicen, tampoco debe de estar en el espiritual y místico, de que tan llenos están todos los Santos, pues dice el dicho fray José que los Santos dicen sus pensamientos, pero no los del autor que declaran algunas veces; de donde colige este testigo que este mysterium regni Dei o es otro sentido anagórico $[s i c]$ o literal, diferente del que comúnmente reciben los Santos ... Item dice 
This arcane mystery hiding in the word of God led Arias Montano to a unique brand of exegesis, which his detractors saw as a sort of new literal meaning of Scripture. This is how his De arcano sermone (On hidden language) ${ }^{60}$ is to be interpreted. While it is beyond the scope of this paper to discuss the complex nature of this work, in which Arias Montano said he had 'written a book in which, as briefly and clearly as possible, we have reflected not so much the translations of the words, but rather their properties, nature and essence, ${ }^{61}$ it is indeed fitting to point out a certain resemblance with Valdés insofar as his group is structured around a particular direction in Bible interpretation.

In terms of what Arias Montano meant by literal meaning, we might recall that, as Zur Shalev has recently pointed out in a study on Arias Montano's Geographia Sacra (Sacred Geography), his geographical work is built on a literal and historical understanding of Scripture. Along these lines, Shalev discusses other approaches that have dealt with the study of maps in Bibles as part of the history of the Reformation, because of its emphasis on the literal over the allegorical. ${ }^{62}$ This had also been a crucial aspect of the exegetical work by Miguel Servet, which was heavily influenced by Judaism and centered around an extremely literal interpretation of the Old Testament, which, unlike Christian exegesis, he saw as a historical text and not as a prefiguration of Christ. ${ }^{63}$ This prefiguration is the cornerstone of the allegorical interpretation of the Bible. Indeed, allegory constituted a clear dividing line with both Judaism and the reformed world. This is key to understanding the crucial importance of literalism, which sprang up quite abruptly in the aforementioned Inquisitorial proceedings against Fray Luis.

One essential aspect in which these problems surrounding the literal interpretation of the Bible are expressed is the issue of its translation, which in this period is inseparably tied to the problematic relationship with Hebrew and Judaism. Apart from the examples that have already been given (for example Fray José de Sigüenza penned several biblical translations and a narrative

este testigo que para comunicar este misterio ... piden no sabe qué disposición en los discípulos'; Andrés, Proceso inquisitorial, p. 237.

60 Benito Arias Montano, Libro de José o sobre el lenguaje arcano, (eds. and trans.) Luis Gómez Canseco et al. (Huelva: Universidad de Huelva, 2006), p. 66.

61 'escrito un libro, en el que, con la brevedad y claridad que nos ha sido posible, hemos reflejado no tanto las traducciones de las palabras como las propiedades, naturaleza y esencia de las mismas'; Arias Montano, Libro de José, p. 91.

62 Zur Shalev, Sacred Words and Worlds: Geography, Religion and Scholarship, 1550-1700 (Leiden: Brill, 2012), p. 27 and p. $5^{2}$ n. 57.

63 Jerome Friedman, 'Michael Servetus: the Case for a Jewish Christianity', The SixteenthCentury Journal, 4 (1973): pp. 87-110. 
account of the life of King David), ${ }^{64}$ the best known case is, without a doubt, that of Fray Luis de León and the Inquisitorial proceedings he was subjected to alongside other Hebraists from the University of Salamanca, a case which I will not discuss in depth in this essay. What is worth noting, however, is that in spite of the prohibition against translating the Bible into the Romance vernacular, people continued to make these translations, at times even openly.

A remarkable example is that of Francisco de Quevedo (1580-1645), who carried out rather interesting work as a Hebraist and Hebrew translator as part of his attempts to become a recognized scholar. One of his most interesting translations is that of the Lamentations of Jeremiah. The title of the work is Lágrimas de Hieremías castellanas ordenando y declarando la letra hebrea, con paráphrasiy comentarios (Tears of Jeremiah in Spanish, ordering and clarifying the Hebrew writing, with paraphrases and commentaries), and clearly indicates that it contains a literal translation of the Lamentations, plus paraphrases and commentary. ${ }^{65}$ Without going into more detail, suffice it to recall the fact that, for his literal version, Quevedo's main reference was the Ferrara Bible. Beyond his explicit aims ('to give unto my language this paraphrase' and 'to give reasons in defense of the Vulgate'), one might raise questions about the influence on Spanish literature of Jewish Romance vernacular translations of the Bible. Here, it is worth mentioning that Quevedo himself thought that 'Spanish and Hebrew were intimately related', which led him to believe that many Spanish idioms were of Hebrew origin. ${ }^{66}$ Later on, Quevedo would write that 'there is no language that fits the style of Hebrew more or better than our own, since it has the same grammar, as we shall one day demonstrate.67 This is an argument that he expressed at length in his España defendida (Spain defended), ${ }^{68}$ which is a work that, like so many others of its time, proposed to defend Spain against the works of some European scholars who, as in the case of Scaliger, were perceived to write against Spain on religious grounds. In this case, Quevedo explicitly stated that this grammatical closeness between Spanish and Hebrew could best be seen in translations from Hebrew. This was, ultimately, an argument in favor of the extreme antiquity of Spanish, which

64 Andrés, El proceso inquisitorial, p. 140, n. 59.

65 Francisco de Quevedo, Lágrimas de Hieremías catellanas, (ed.) Edward M. Wilson and José Manuel Blecua (Madrid: CsIC, 1953). See also Natalio Fernández Marcos and Emilia Fernández Tejero, '¿Quevedo hebraísta? Lágrimas de Hieremías castellanas', Sefarad, 62 (2002): pp. 309-28; Valentín Núñez Rivera, 'Quevedo y la traducción bíblica: traducciones y contextos. (En torno al Cantar de los Cantares)', La Perinola, 10 (2006): pp. 225-43.

66 Wilson and Blecua, 'Introducción' to Quevedo, Lágrimas, p. cii.

67 Wilson and Blecua, 'Introducción' to Quevedo, Lágrimas, p. civ.

68 Fernández and Fernández, ‘¿Quevedo hebraísta?', p. 321, n. 55. 
had not taken anything from Greek or Latin and, as such, was a language with more authority than either of the latter.

One might point out, in this same genre of national apology mixed with sacred history, works such as Pablo Yáñez de Avilés, España en la santa Biblia (Madrid: Juan Muñoz, 1733), which makes use at length of Arias Montano's commentary to Obadiah, supporting the idea that there was mention of Spain in the Bible. This is a topic that first showed up in Spanish historiography with Arias Montano, and which stirred up a great deal of controversy. However, in a book like that of Yáñez, it ended up becoming a full-fledged account of the sacred history of Spain based on its would-be presence in the Bible. Needless to say, this argument should be situated within a wider context, that of the controversy surrounding the antiquity of the Spanish language, upheld as an argument for imperial legitimation, and connected to a contemporary historiography that was obsessed with the ancient history of Spain and the possibility of it having taken part in sacred history.

Of course, this notion was based on the widespread conception that Hebrew was the original language of humanity. Quevedo's argument is extremely close to that used, just a few years prior, by Diego de Guadix (d. 1615), who held that a significant portion of Spanish descended from Arabic, a language that was much older than Latin, and which was ultimately just 'corrupted Hebrew'. In general, defending the Arabic or Hebrew origins of Spanish is an argument that may be understood within the broad cultural context of attempts to link Spanish history to sacred history, represented by the Biblical East. ${ }^{69}$

The example of Quevedo serves to illustrate two important aspects here. First, it makes it possible to qualify the history of how vernacular translations of the Bible were banned in early modern Spain. Alongside episodes of persecution and censorship, biblical texts continued to be translated into a variety of registers and their translations continued to circulate. One example of this could be Quevedo himself, who translated several books from the Bible, which he used to illustrate some of his own works, such as Política de Dios, gobierno de Cristo y tiranía de Satanás (Politics of God, Government of Christ and Tyranny of Satan), in which his support for Christ as a political model is accompanied by long passages translated from the Gospels. The controversy surrounding the translation of the Bible is a long one indeed, and in it the issue of literal versus

69 Some examples of the cultural, linguistic and dogmatic tension between a certain model of Arab-Hispanic Christianity and Eastern Arab Christianity may be found in Mercedes García-Arenal and Fernando Rodríguez Mediano, 'Los libros de los moriscos y los eruditos orientales', Al-Qanțara, 31 (2010): pp. 611-46. 
mystical meaning is a central theme. For example, in Furió Ceriol's dispute with Giovanni de Bononia this topic takes on a variety of forms. For Furió Ceriol (1527-92), Hebrew was, ultimately, just another vernacular tongue that God had made use of in order to transmit His message. Moreover, Hebrew was not a particularly refined language: in fact, he found the accent of Biblical Hebrew to be particularly repugnant. ${ }^{70}$ As for Bononia, he considered, among other things, that the Biblical languages were untranslatable; Hebrew was a language that had been subject to change over the centuries, and was understood by very few people, including the rabbis, for which reason it was especially important to maintain the original Hebrew form, particularly in the case of legal terms. ${ }^{71}$

Furió Ceriol's book is crucial in the long controversies surrounding the translation of the Bible into Spanish. Without entering into the details of these controversies, suffice it to briefly recall the way in which the defense of translating the Bible into vernacular, insomuch as it entailed criticism of the church's mediating role as authorized institution of interpretation, went hand in hand with a criticism of the Vulgate as a poor translation. One of the most important Spanish Protestant texts of the seventeenth century, Fernando de Texeda's Carrascón, turns to the authority of Arias Montano to back up its biting criticism of papism and the Vulgate, listing out all of the problems inherent to biblical translation: (1) what is ambiguous in one language cannot always be ambiguously translated; (2) it often happens that what in the source language means something specific is translated ambiguously and dubiously by the interpreters; (3) frequently, something that has a clear meaning in the source language becomes obscure in the translation; (4) the interpretation, which

Els Agten, 'Fadrique Furió Ceriol, Giovanni di Bononia y la traducción de la Biblia en lengua vernácula. Análisis del Bononia (1556)', Mayéutica, 36 (2010): pp. 61-9o. The argument that Hebrew itself is ultimately just a vernacular language used to communicate God' law to a relatively unrefined people is used in several places. For example, it is used by Francisco de Enzinas in the justification of his translation of the Gospels, 'To the most unconquered monarch Carlos v'; El Nuevo Testamento de nuestro Redemptor y Salvador Jesu Christo (Antwerp: Steven Mierdman, 1543).

71 This argument continues the age-old debate over the special need to maintain the literalism of legal terms and leads us to a fundamental aspect of the Bible, that of legal text. This is a complex topic, which opens up the field to a fundamental problem of modern political and legal thought. The bridge between the 'old law' and the 'new law' is largely built upon the figure of St Paul: for example the text by another disciple of Arias Montano, Pedro de Valencia, 'Para declaración de una gran parte de la estoria apostólica en los Actos y en la Epístola Ad Galatas, Advertencia', in Obras completas, Vol. II. Escritos bíblicos y teológicos, (coord.) Jesús M. Nieto Ibáñez (León: Universidad de León, 2014). 
originates from the source, lacks the latter's purity and elegance; (5) 'in the source language there are many metaphors and many genres and types of devices that interpreters cannot possibly translate with the same correctness, skill and elegance of meaning'; (6) there are many errors caused by booksellers and printers, which cannot be corrected, whereas the Hebrew text has preserved its purity; (7) sometimes heretics, out of malice, corrupt the Latin interpretation of the holy books; (8) sometimes Scripture is so rich that it has two meanings, 'which mostly happens when the prayer contains rhetorical devices, embellishments and allegories. In this genre it is the source language that reigns supreme and, as everyone knows, surpasses all the rest, because it has an infinite number of locutions with nearly infinite meanings; something so rare, unique and particular to it that it is not found in any other language.' ${ }^{2}$

The Carrascón serves as a reminder that the controversy over translation and, most of all, over how to interpret the Bible, falls right on the borderline between the Reformation and the Counter-Reformation. As we have already seen, the most important translations of the Bible into Spanish belong to the realm of Protestantism. This fact, and the resulting and growing persecution of biblical translations in Spain starting in the mid-sixteenth century, should not lead us to think that the Bible was not translated in Spain, nor that the text of the Bible did not circulate in different forms and genres, as the aforementioned example of Quevedo goes to show, or in a variety of registers. In one of the prologues to his Paráphrasis de los Psalmos de David, (Paraphrase of the Psalms of David), Antonio de Cáceres y Sotomayor (1552-1615) explained his reasons for writing the paraphrase. He recalled a certain nun who used to tell him that

one of the greatest sorrows that her spirit felt during her constant choral work was to always say and sing the same thing without ever understanding it, and that she was deeply envious of monks, for she thought that their devotion and spirit must necessarily grow a great deal, given that they understand what they are singing.

72 'en el idioma primero hay muchas translaciones y muchos jéneros y modos de figuras que es del todo imposible traduzgan los intérpretes con igual propiedad, primor y gala de la significación'; lo cual sucede mayormente cuando la oración consta de figuras, adornos y alegorías. En el cual jénero, la lengua primera es príncipe y, como saben todos, excede a todas, porque infinitas dicciones della contienen significaciones casi infinitas; cosa tan rara, tan peculiar y propia a ella que no se halla en otra lengua'; Fernando de Texeda, Carrascón, 2nd ed. (sl.: s.n., 1847), p. 147ff. 
In her anguish, this nun 'would always search within herself for Spanish words bearing some resemblance to the words from the Psalms that she says in Latin, believing that in this way a special spirit awakens in her heart and her soul draws new breath'; which lead to outlandish interpretations of the Psalms. Cáceres was of the opinion that

reducing to the phrasing of Spanish the Psalms that David wrote with such spirit, enclosing in them countless sacraments and many different meanings, which Hebrew, being by its nature so mysterious and full of meaning, was able to comprise, is something I am not sure can be done in any other language of those that we currently know, including Latin and Greek, particularly if they are to give the Psalms ... the many varied meanings that up till now the holy doctors have given them.

So, if translating them into Spanish was already a difficult task, all the more so was reducing them 'to our language's own phrasing and manner of speech by creating a paraphrased version', for this would amount to asking 'for me to say David's verses in the Spanish vernacular, with the mysterious brevity with which the Prophet would have spoken them if he had been made to write them using the phrasing of Spanish', which seemed impossible, since no language could express 'so much doctrine and such different meanings' as were enclosed in the Psalms. Moreover, it could 'stand in the way of the merits of faith' for women to understand what they were singing. And yet, so as to not leave 'the mothers full of sorrow', Cáceres decided to go ahead with his paraphrase of the Psalms. ${ }^{73}$ The problem of women's relationship with Scripture

'uno de los mayores desconsuelos que sentía su spíritu en el continuo exercicio del coro era dezir y cantar siempre lo mesmo sin entendello más un día con otro, y que tenía grande invidia a los religiosos, pareciéndole que de necesidad avían de medrar mucho en la devoción y en el spíritu, pues entienden lo que cantan ...'; 'andava buscando siempre entre sí mesma palavras castellanas que se pareciessen en algo a las palavras de los Psalmos que ella dize en latín, pareciéndole que por aquel camino se despierta en su coraçón un particular spíritu y cobra su alma nuevo aliento ...'; 'reduzir al frasis de la lengua castellana los Psalmos que escrivió David con tanto espíritu, encerrando en ellos innumerables sacramentos y muchos y diferentes sentidos, que la lengua hebrea, por ser de suyo tan mysteriosa y significativa pudo comprehender, no sé yo que sea cossa que pueda hazerse en ninguna otra lengua de las que agora conocemos, aunque sea la lengua latina y la griega, particularmente si se les han de dar a los Psalmos ... los sentidos muchos y varios que los doctores santos les han dado hasta ahora ...; 'al phrasis y modo de hablar propio de nuestra lengua por versión paraphrástica'; 'que diga yo en romance castellano los versos de David, con la brevedad mysteriosa que los dixera el Profeta si le obligaran a que los 
and its translation, and the type of spirituality that this tension defines, is the main topic of a short piece by St Teresa of Ávila (1515-82), Meditaciones sobre los Cantares (Meditations on the Song of Songs), which has been interpreted as one of the pillars of the Saint's opposition to the world of scholarship. ${ }^{74}$

In this regard, we might cite the case of Fray Luis de León's translation of the Song of Songs, which was at the root of a number of his run-ins with the Inquisition. First of all, the literal translation of the text was dedicated to a nun, Isabel Osorio, who likewise did not understand Latin but sought insight into the literal meaning of Scripture. In this case, the problem of the sacred text's intelligibility also poses the issue of feminine spirituality. However, more than just an instance of gender-specific expression, it serves as an example of a fragmentary, partial manner of disseminating the Bible, one which depends on particular circumstances, on the relationship between translator and audience, and on different lines of transmission (printed or manuscript) or the use of diverse literary genres.

Moreover, the example of Quevedo is enlightening as it illustrates the influence exerted on Spanish Bible translations by the tradition of Romance Bible translations carried out by Jews. Quevedo is of course by no means the only one who followed the translation of the Ferrara Bible. Other examples could be cited, starting with Casiodoro de Reina's translation, the so-called Biblia del Oso, a crucial text for the Spanish reformed Bible. In the 'Reader's Introduction', Casiodoro admits that, 'for such needs we have made use of the old Spanish Translation of the Old Testament, printed in Ferrara, more than any other work that we have seen till now, not so much because it is any more correct than the rest in such cases, but rather because it has provided us with the natural and principal meaning of the Hebrew words, as well as the differences between the verb tenses, since they are found in a single text, for which reason it is a work that should be held in higher esteem ... than any other to date. And due to this

escriviera en el phrasis de la lengua castellana'; 'tanta doctrina y tan diferentes sentidos'; 'podría estorvar al mérito de la fe'; Antonio de Cáceres y Sotomayor, 'Carta del autor siendo frayle, en respuesta de otra de una devota religiosa, pidiéndole que hiziesse esta obra, la qual sirve de proemio' (Letter by the author, a monk, in response to another by a devout nun asking him to write this piece, serving as a prologue), Paráphrasis de los Psalmos de David, reduzidos al phrasis y modos de hablar de la lengua española, en el sentido en que los dixo el Propheta según que los entienden los Sanctos (Paraphrase of the Psalms of David, reduced to the phrasing and manners of speech of Spanish, with the meaning with which the Prophet spoke them as understood by the Saints. Lisbon: Pedro Crasbeeck, 1616).

74 Aurora Egido, 'Santa Teresa contra los letrados. Los interlocutores en su obra', in El águila y la tela (Palma, Barcelona: José J. de Olañeta, Edicions UıB, 2010), pp. 47-77. 
unique assistance, which other translations have not enjoyed, we hope that our own will at least not be inferior to any of them. ${ }^{75}$

The importance of the Hispanic tradition of Romance Bible translations may serve to exemplify an even larger issue, which is also illustrated by the example of Quevedo: the existence in Modern Spain of an eastward-looking cultural model that joined together the interpretation of the Iberian peninsula's Muslim past and the writing of a sacred history of Spain. The spread of this model was to have a number of consequences in terms of legal, political and other forms of thought.

\section{Conclusion}

The examples cited throughout this article may be read in a variety of ways involving overlapping arguments. Some of these arguments are:

- There is no single history of the translation of the Bible into the vernacular Romance languages in early modern Spain. We know from a number of documents that, starting in the mid-sixteenth century, translation into Romance was persecuted by the Inquisition, and we also know that there was a general understanding that the Bible should not circulate in the Romance vernacular. However, at the same time, we know that translations of the Bible were in fact made, and that biblical texts in Romance vernacular circulated in a variety of ways (in political treatises, paraphrases, etc.).

- The problem of translating the Bible shows up continually. Whether in Catholic or Protestant contexts, such translations frequently look to the medieval tradition of translations into Romance vernacular that were carried out by Jews. This tradition highlights the problem of literal translation, which is connected to the issue of literal or allegorical interpretation. Of course, the authority of the Vulgate is at the center of the controversies surrounding the translation or interpretation of the Bible. Ultimately, part of the arguments as to the impossibility of translating the Bible could be applied in turn to the

'de la vieja Traslación española del Viejo Testamento, impressa en Ferrara, nos avemos ayudado en semejantes necesidades más que de ninguna otra que hasta aora ayamos visto, no tanto por aver ella siempre acertado más que las otras en casos semejantes, quanto por darnos la natural y primera significación de los vocablos hebreos, y las differencias de los tiempos de los verbos, como están en el mismo texto, en lo qual es obra digna de mayor estima ... que quantas hasta aora ay; y por esta tan singular ayuda, de la qual otras translaciones no han gozado, esperamos que la nuestra por lo menos no será inferior a ninguna de ellas'; De Reina, 'Al lector', in La Biblia, que es los sacros libros del Viejo y Nuevo testamento, trasladada en español (Basilea: Thomas Guarin, 1569). 
Vulgate, itself a translation. The examples of Furió Ceriol, Bononia or Texeda illustrate the varied uses of arguments as to the feasibility (or lack thereof) of translating from the Hebrew and capturing the meanings of the original text.

- The problem of interpretation constitutes a major fault line, as the Catholic polemic against the exclusivity of literal interpretation signals a divide with the reformed world, as well as with Judaism. One fundamental reason is that allegory (for example the allegory of Christ) is the basic figure in the relationship between the Old and New Testaments. This Christological foundation of allegory reaches a unique expression with the reflection on the Eucharist, which in turn forms the basis of a reflection on representation.

- The translation of the Bible also raises the issue of the relationship between Spanish and Hebrew and, more broadly, the use of the Bible as a linguistic and literary model. This issue takes on a variety of forms: the reflection on the origin of Spanish and its relationship with other Eastern languages; the borrowing of narrative, poetic or rhythmic forms; the genres of the Bible, whether poetic or historical. The underlying issue behind most of these reflections is that of writing sacred history, or that of the relationship between the various literary genres on the one hand, and sacred history on the other.

- The translation of the Bible and, more specifically, its translation into the vernacular, entails a discussion about intelligibility. In this context, intelligibility involves two dimensions. On the one hand, this relates to the intelligibility of the language and style, which was an important issue in the period's literary debates. This reason explains, in part, the references to the proper style and verse for writing sacred narratives, as well as to their simplicity. Along these lines, intelligibility also means the opposition between ignorant spirituality and erudite spirituality. This tension may be found in the cited example of St Teresa of Ávila, but also in that of Lope de Vega, who tellingly compared the literary and spiritual models of St Isidore of Seville and St Isidore the Farm Laborer. With added complexity, it is a problem that may also be found in Juan de Valdés, for whom understandability provides the framework for a spiritual path. One might wonder at the relationship between this debate surrounding ignorance vs. erudition, and spiritual or illuminist forms of religiosity.

- Since allegory is a fundamentally historical device articulating the narration of sacred history around Christ, it is eventually applied to the interpretation of various non-biblical traditions, such as classical mythology, and ultimately constitutes the foundation of an interpretive model of history based on prisca theologia (ancient theology). From this perspective, a realistic or sarcastic approach to classical myth, or to the limits of the narrative genres, could also be taken to express criticism of a global model of interpretation based, to a certain extent, on the interpretation of the Bible, which is essentially a radical critique of the models of authority. 